\title{
PENGGUNAAN FERRI KLORIDA DAN KITOSAN CANGKANG KEPITING SEBAGAI ALTERNATIF KOAGULAN PADA PENGOLAHAN AIR LIMBAH LAUNDRY
}

\section{THE USE OF FERRI CHLORIDE AND CRAB SHELL CHITOSAN AS AN ALTERNATIVE COAGULANTS IN LAUNDRY WASTEWATER TREATMENT}

\author{
Adhi Setiawan, Citra Eripramita Yunus, Tarikh Azis Ramadani, \\ Novi Eka Mayangsari \\ Program Studi Teknik Pengolahan Limbah, Politeknik Perkapalan Negeri Surabaya (PPNS) \\ Jl. Teknik Kimia Kampus ITS Sukolilo-Surabaya, Indonesia 60111 \\ e-mail: adhistw23@gmail.com
}

Diterima : 02-10-2019

Direvisi : 28-11-2019

Disetujui : 03-12-2019

\begin{abstract}
ABSTRAK
Pembuangan air Limbah laundry secara langsung di aliran sungai menjadi penyebab tingginya pencemaran sungai. Air limbah laundry mengakibatkan peningkatan perameter $C O D, B_{5}$, serta $M B A S$ sehingga berdampak negatif pada kehidupan ekosistem. Proses koagulasi menggunakan bahan kimia $\mathrm{FeCl}_{3}$ dapat menurunkan parameter $\mathrm{COD}, \mathrm{BOD}_{5}$ dan MBAS dalam air limbah namun menimbulkan efek negatif pada kesehatan. Kitosan dari cangkang crustacea dapat digunakan sebagai alternatif koagulan yang ramah lingkungan. Kombinasi koagulan kitosan dan $\mathrm{FeCl}_{3}$ diharapkan mampu menurunkan parameter $\mathrm{COD}, \mathrm{BOD}_{5}$ dan MBAS air limbah laundry serta dapat mengurangi dosis penggunaan koagulan kimia.Penelitian ini bertujuan mensintesa biokoagulan kitosan dari cangkang kepiting serta menguji efektivitas kitosan cangkang kepiting, ferri klorida, dan kombinasi kedua koagulan dalam pengolahan air limbah laundry. Proses deasetilasi cangkang kepiting menjadi kitosan menggunakan larutan $\mathrm{NaOH}$ $60 \%$ pada suhu $125^{\circ} \mathrm{C}$ selama 6 jam. Koagulasi dilakukan terhadap air limbah menggunakan tiga jenis koagulan yaitu ferrri klorida, kitosan, dan ferri klorida-kitosan. Hasil penelitian menunjukkan bahwa dosis optimum penggunaan koagulan kombinasi terjadi pada dosis $40 \mathrm{mg} / \mathrm{L}$ kitosan dan $100 \mathrm{mgl} / \mathrm{L}$ ferri klorida dengan menghasilkan efisiensi penyisihan $\mathrm{COD}, \mathrm{BOD}_{5}$, dan MBAS masing-masing sebesar $71,67 \%$, 81,14\%, dan 66,24\%. Penggunaan kombinasi koagulan pada dosis optimum dapat menghemat pemakaian ferri klorida sebesar $84 \%$.
\end{abstract}

Keywords: Air limbah laundry, ferri klorida, kitosan, koagulasi.

\section{ABSTRACT}

Disposal Laundry wastewater directly in the river were the cause of high river pollution. Laundry wastewater were resulted in an increase the parameters of $C O D, B O D_{5}$, and MBAS, which has a negative impact on river ecosystem. The coagulation process used the chemical $\mathrm{FeCl}_{3} \mathrm{can}$ reduce the parameters of COD, BOD5 and MBAS in wastewater but cause negative effects on health. Chitosan from crustacean shells can be used as an alternative to environmentally friendly coagulants. The combination of chitosan coagulant and $\mathrm{FeCl}_{3}$ is expected to reduce the parameters of $\mathrm{COD}, B O D_{5}$, and MBAS laundry wastewater and can reduce the dose of the use of chemical coagulants. This research aims to synthesize chitosan bio-coagulants from crab shell and to test the effectiveness of chitosan crab shell, ferric chloride, and the combination of both coagulants in laundry wastewater treatment. The process of deasetilation of crab shells into chitosan using $60 \% \mathrm{NaOH}$ solution at $125^{\circ} \mathrm{C}$ for 6 hours. Coagulation was carried out on wastewater using three types of coagulants, namely ferric chloride, chitosan and ferric chloride-chitosan. The results showed that the optimum dose of the use of a combination of coagulants occurred at a dose of $40 \mathrm{mg} / \mathrm{L}$ chitosan and $100 \mathrm{mg} / \mathrm{L}$ ferric chloride with removal efficiency of COD, BOD 5 and MBAS were 
$71.67 \%, 81.14 \%$, and $66,24 \%$ respectively. Coagulant combination at the optimum dosage can save the used of ferric chloride by $84 \%$.

Keywords: chitosan, coagulation, ferric chloride, Laundry wastewater.

\section{PENDAHULUAN}

D enggunaan air pada aktifitas industri seperti halnya pada proses produksi, utilitas, serta sanitasi menghasilkan limbah cair dalam volume yang besar. Air limbah yang dihasilkan dari aktifitas industri berpotensi menyebabkan pencemaran lingkungan akuatik apabila tidak diolah secara tepat. Beberapa Kandungan kontaminan di dalam air limbah dapat bersifat karsinogenik dan mutagenik terhadap makluk hidup yang hidup di dalam medium tersebut (Silva et al., 2016). Proses industrialisasi memberikan kontribusi cukup besar terhadap polusi lingkungan (udara, air, dan tanah), degradasi lingkungan, penipisan sumber daya, dan ancaman terhadap kesehatan manusia akibat paparan zat berbahaya dari limbah industri (Adesoye et al., 2014). Aktifitas yang telah dilakukan manusia selama bertahun-tahun dalam berbagai hal seperti pembuangan limbah, kontaminasi racun melalui logam berat, limpasan pertanian dan urbanisasi telah menurunkan kualitas air. Air limbah perkotaan pada umumnya terdiri dari air limbah rumah tangga, perusahaan komersial, dan air tanah atau air permukaan yang masuk ke dalam sistem pembuangan kotoran (Middleton, 1997). Industri laundry merupakan salah satu penyumbang air limbah perkotaan yangmemiliki kandungan COD, $\mathrm{BOD}_{5}$, dan surfaktan yang relatif tinggi sehingga menjadi penyebab tingginya tingkat pencemaran air sungai (Nascimento et al., 2019). kadar COD dan BOD $_{5}$ tersebut disebabkan oleh tingginya beban organik. Selain itu, kadar deterjen berupa surfaktan anionik (MBAS) dalam jumlah yang tinggi dapat membentuk busa yang menutup permukaan badan air. Hal ini menyebabkan penurunan kandungan oksigen terlarut di dalam badan air.

Air limbah industri laundry memiliki karakteristik kandungan fosfat, surfaktan, nutrisi, kekeruhan, BOD, dan COD karena keberadaan kotoran dan residu detergen serta pelunak yang digunakan selama proses pencucian (Braga dan Varesche, 2014). Karakteristik tersebut disebabkan oleh penggunaan detergen pada proses pencucian. Kandungan detergent pada badan air yang relatif tinggi menyebabkan pencemaran lingkungan serta berpotensi meningkatkan level eutrofikasi pada ekosistem sungai. Beberapa metode yang sering digunakan pada pengolahan air limbah laundry pada umumnya didasarkan pada kombinasi proses biologi, fisik, kimia seperti halnya elektrokoagulasi, proses pemisahan membran, membran bioreactor, adsorpsi, dan koagulasi (Ge et al., 2004; Janpoor et al., 2011).

Proses koagulasi-flokulasi merupakan metode yang terbukti efektif dalam menghilangkan material organik dengan biaya operasional yang relatif rendah. Proses koagulasi tersebut dapat menggunakan koagulan alami maupun anorganik yang tersedia dipasaran (Terechova et al., 2014). Penggunaan koagulan anorganik berbasis aluminium dan besi seringkali digunakan menurunkan kadar COD dan padatan tersuspensi yang terkandung di dalam air limbah laundry. Proses pengolahan tersebut cenderung menghasilkan sludge dalam jumlah besar akibat pembentukan logam hidroksida serta turbiditas yang tinggi. Bahkan, proses sedimentasi dengan volume sludge yang tinggi berpotensi menghentikan proses pengolahan air limbah. Selain itu, konsentrasi residu ion ferri atau aluminium dalam air dapat meningkat karena peningkatan dosis koagulan kimia. Hal ini dapat meningkatkan risiko penyakit Alzheimer, anemia, hilangnya memori, dan gejala sakit kepala (Nascimento et al., 2019; Muthuraman dan Sasikala., 2014).Polimer sintetik seperti poli akrilamida dan poliamina merupakan koagulan alternatif yang dapat digunakan untuk proses pengolahan air limbah dengan koagulasi-flokulasi. Penggunaan kedua bahan kimia tersebut efektif dalam mengurangi kekeruhan air limbah tanpa peningkatkan volume lumpur karena tidak menghasilkan logam hidroksida. Namun, masalah kesehatan terkait dengan pelepasan oligomer karsinogenik menyebabkan penggunaannya cukup terbatas. 
Pengembangan koagulan ramah lingkungan sebagai pengganti koagulan kimia cukup meningkat karena peningkatan kesadaran masyarakat akan pentingnya aspek kesehatan dan lingkungan. Polimer organik alami (biopolimer) dapat diproduksi secara alami atau diekstraksi dari hewan, jaringan tanaman, atau mikoorganisme (Zemmouri et al., 2013).Kitosan merupakan salah satu jenis biopolimer yang dapat disintesis dari limbah cangkang crustacea seperti kepiting serta dapatdiaplikasikan sebagai alternatif pembuatan biokoagulan. Kitosan merupakan biopolimer kationik yang terbentuk dari deasetilasi parsial komponen kitin oleh alkali $\mathrm{NaOH}$. Struktur kitosan berbentuk aminopolisakarida hidrofilik linier dengan struktur kaku yang terdiri dari unit glukosamin dan asetil glukosamin. Masing-masing unit glukosamin terdiri dari kelompok amino bebas $\left(-\mathrm{NH}_{2}\right)$. Gugus amino tersebut sebagai polielektrolit yang bersifat multifungsi dan berperan dalam pembentukan flok (Mashitah et al., 2017).

Beberapa kelebihan penggunaan kitosan sebagai biokoagulan antara lain tidak beracun bagi manusia, mudah terurai (biodegradable), mampu mentreatment partikel koloidal, COD, dan logam berat yang terkandung di dalam air limbah (Bergamasco et al., 2011). Penggunaan biokoagulan kitosan cukup efisien pada dosis rendah sehingga dapat mengurangi volume lumpur (Renaut et al., 2009). Namun, kitosan harganya relatif lebih mahal dibandingkan dengan koagulan kimia.Ferri klorida $\left(\mathrm{FeCl}_{3}\right)$ merupakan garam anorganik yang dapat digunakan sebagai koagulan pada pengolahan air limbah karena memiliki karakteristik adsorpsi, koagulasi, serta presipitasi (Daud et al., 2013).Penggunaan $\mathrm{FeCl}_{3}$ pada sistem perpipaan logam seringkali menimbulkan problem korosi yang cukup serius, sulit dilarutkan, serta menghasilkan konsentrasi besi terlarut yang cukup tinggi pada effluent proses (Sahu dan Chaudari, 2013). Kombinasi koagulan kitosan dan $\mathrm{FeCl}_{3}$ diharapkan mampu memperbaiki kinerja pengolahan air limbah laundry menggunakan proses koagulasi-flokulasi.

Penelitian sebelumnya menunjukkan bahwa penggunaan kitosan dapat menurunkan konsentrasi COD hingga $72,67 \%$ dan kekeruhan sampai dengan $98,67 \%$ dengan dosis 200 $\mathrm{mg} / \mathrm{L}$ pada limbah laundry (Putri et al., 2015). Larasati et al. (2017) melaporkan bahwa penambahan dosis ferri klorida sebanyak $1,5 \mathrm{~g} / \mathrm{L}$ dapat menurunkan kadar COD pada limbah laundry sebesar $73,79 \%$. Beberapa peneliti telah menginvestigasipenggunaan koagulan kombinasi PAC-kitosan memiliki efek removal warna lebih baik dibandingkan penggunaan koagulan PAC maupun kombinasi koagulan Al-Fe (Zheng et al., 2017). Hongxia dan Yaocang (2012) menggunakan kombinasi koagulan PAC dan kitosan dalam mengolah limbah air limbah domestik. Penggunaan koagulan kombinasi meningkatkan efisiensi removal COD dan kekeruhan masing-masing sebesar $36,5 \%$ dan $21,5 \%$ dibandingkan dengan hanya menggunakan PAC. Zemmouriet al. (2013) menggunakan kombinasi chitosan-alum untuk mentreatment air dam dengan metode koagulasi-flokulasi. Persen removal diperoleh sebesar $97 \%$ menggunakan dosis 0,2 mg/L kitosan.

Beberapa penelitian sebelumnya lebih banyak menginvestigasi tentang kinerja koagulan tunggal kitosan maupun ferri klorida dalam pengolahan limbah cair laundry. Bahkan, informasi tentang penggunaan serta kinerja kombinasi koagulan kitosan dengan ferri klorida pada pengolahan limbah laundry masih belum dijelaskan secara detail.Penelitian ini bertujuan sintesis biokoagulan kitosan dari limbah cangkang kepiting serta menguji efektivitas kitosan cangkang kepiting, ferri klorida, dan kombinasi kedua koagulan dalam pengolahan limbah laundry.

\section{METODE PENELITIAN Alat dan Bahan}

Alat yang digunakan pada penelitian ini antara lain oven, ayakan ukuran $25 \mathrm{~mm}$, hot plate dan magnetic stirrer, peralatan jar test, serta Fourier Tranform Infrared (FT-IR) (Thermo Scientific Nicolet iS10) pada panjang gelombang $4000-400 \mathrm{~cm}^{-1}$. Bahan yang digunakan pada penelitian ini antara lain limbah cangkang kepiting yang diperoleh dari rumah makan seafood 
di Surabaya, padatan $\mathrm{FeCl}_{3}$ (SAP) larutan $\mathrm{HCl} 37 \%$ (SAP), padatan $\mathrm{NaOH}$ (Merck), etanol 70\% (SAP), asam asetat $1 \%(\mathrm{SAP})$, larutan $\mathrm{H}_{2} \mathrm{SO}_{4} 98 \%$ (Merck), $\mathrm{AgNO}_{3}$ (Merck), limbah laundry dari salah satu penyedia usaha laundry (daerah Bulak, Surabaya), dan akuades.

\section{Sintesis Kitosan}

Proses sintesis kitosan dari limbah cangkang kepiting dibagi menjadi empat tahap yaitu preparasi, demineralisasi, deproteinasi, dan deasetilasi (Al Manhel et al., 2018). Tahap preparasi dilakukan dengan merebus cangkang kepiting dilanjutkan pencucian dengan airuntuk menghilangkan kotoran yang melekat. Cangkang kepiting selanjutnya dikeringkan di dalam oven pada suhu $110^{\circ} \mathrm{C}$ selama kurang lebih satu jam. Sampel yang telah kering dihancurkan dandiayak menggunakan ayakan $0,25 \mathrm{~mm}$ sehingga diperoleh serbuk dengan ukuran yang seragam.

Tahap demineralisasi dilakukan dengan penambahan serbuk cangkang kepiting ditambahkan larutan $\mathrm{HCl}$ 1,5 $\mathrm{M}$ dengan perbandingan massa sampel (gr) dengan volume larutan asam $(\mathrm{mL})$ sebesar $1: 15$. Campuran dipanaskan pada suhu $70-80^{\circ} \mathrm{C}$ selama 4 jam sambil dilakukan pengadukan pada $50 \mathrm{rpm}$. Padatan selanjutnya disaring dan dicuci menggunakan akuades untuk menghilangkan $\mathrm{HCl}$ yang tersisa. Padatan yang terpisah selanjutnya dikeringkan di dalam oven pada suhu $70^{\circ} \mathrm{C}$ selama 6 jam.

Tahap deproteinasi dilakukan dengan pencampuran sampel dari tahap demineralisasi dengan larutan $\mathrm{NaOH} 3,5 \%$ dengan perbandingan massa sampel (gr) dan volume larutan $(\mathrm{mL})$ sebesar $1: 10$. Campuran tersebut dipanaskan pada suhu $65-70^{\circ} \mathrm{C}$ selama 4 jam sambil dilakukan pengadukan pada50 rpm. Padatan selanjutnya disaring dan didinginkan sehingga diperoleh kitin, yang kemudian dicuci dengan akuades sampai pH netral. Filtrat yang diperoleh diuji dengan pereaksi biuret, bila filtrat berubah menjadi biru berarti protein yang terkandung sudah hilang. Kitin yang sudah dicuci ditambahkan $100 \mathrm{~mL}$ etanol $70 \%$ dan dilanjutkan dengan penyaringan. Sampel selanjutnya dikeringkan pada suhu $80^{\circ} \mathrm{C}$ selama 6 jam.

Kitin yang terbentuk dideasetilasi dengan menambahkan larutan $\mathrm{NaOH} 60 \%$ dengan perbandingan massa kitin ( $\mathrm{gr}$ ) dan volume larutan $(\mathrm{mL})$ sebesar 1:20. Campuran diaduk dan dipanaskan pada suhu $125^{\circ} \mathrm{C}$ selama 6 jam. Larutan dipisahkan dan disaring melalui kertas saring. Kitosan yang terbentuk selanjutnya dicuci menggunakan aquadest sampai dengan $\mathrm{pH}$ netral dan dilanjutkan dengan pengeringan di oven pada suhu $80^{\circ} \mathrm{C}$ selama 6 jam. Derajat deasetilasi kitosan kering ditentukan menggunakan metode FTIR. Perhitungan derajat deasetilasi ditentukan menggunakan metode base line yang dapat dihitung menggunakan persamaan (1) sebagai berikut (Mohadi et al., 2014):

$$
D D=100-\left[\left(\frac{A_{1559}}{A_{3572}}\right) \times \frac{100}{1,33}\right]
$$

DD menunjukkan derajat deasitilasi kitosan (\%). $\mathrm{A}_{1559}$ menunjukkan intensitas pita serapan gugus amida pada panjang gelombang $1559 \mathrm{~cm}^{-1} . A_{3572}$ menunjukkan intensitas pita serapan gugus hidroksil pada panjang gelombang $3572 \mathrm{~cm}^{-1}$. Karakterisasi sampel kitosan dilakukan melalui analisis proksimat untuk mengetahui kadar air, abu, lemak, dan protein. Analisis proksimat dilakukan dengan mengacu pada standarAssociation of Official Analytical Chemists (AOAC) tahun 1999. Pembuatan koagulan kitosan dilakukan dengan melarutkan $10 \mathrm{~g}$ serbuk kitosan ke dalam $1000 \mathrm{~mL}$ larutan asam asetat $1 \%$ wt disertai pengadukan sehingga kitosan dapat larut sempurna.

\section{Pengujian Jar Test}

Pengujian kinerja koagulan terhadap penyisihan parameter limbah laundry dilakukan menggunakan metode Jar Test. Volume air limbah laundry yang digunakan pada proses jar test $1000 \mathrm{~mL}$. Pengujian jart test tersebut dilakukan menggunakan tiga variasi jenis koagulan 
yaitu kitosan, ferri klorida, dan kombinasi kitosan-ferri klorida. Percobaan 1 dilakukan penambahan ferri klorida dengan dosis 100, 150, 200, dan $250 \mathrm{mg} / \mathrm{L}$ Percobaan 2 dilakukan penambahan koagulan kitosan dengan dosis yang berbeda-beda yaitu 100, 150, 200, dan 250 $\mathrm{mg} / \mathrm{L}$. Percobaan 3 dilakukan dengan memilihdosis ferri klorida yang memiliki efisiensi penyisihan terkecil pada percobaaan 1 dan dikombinasikan dengan koagulan kitosan pada dosis 20, 40,60, dan $80 \mathrm{mg} / \mathrm{L}$. Jar test dilakukan dengan pengadukan cepat dengan kecepatan kecepatan $150 \mathrm{rpm}$ selama 2 menit dilanjutkan dengan pengadukan lambat pada kecepatan $60 \mathrm{rpm}$ selama 15 menit. Sampel selanjutnya dibiarkan mengendap selama 30 menit.

\section{Analisis Parameter Pencemar}

Analisis parameter dilakukan sebelum dan sesudah melalui proses koagulasi. Tujuan analisis ini adalah untuk mengetahui penurunan konsentrasi beban pencemar setelah mengalami proses pengolahan dengan koagulan kitosan cangkang kepiting, ferri klorida maupun kombinasi kitosan cangkang kepiting dan ferri klorida. Acuan prosedur penelitian yaitu COD (SNI 6989.2-2009), BOD 5 (SNI 6989.72-2009), dan surfaktan anionik/MBAS (SNI 066989.51-2005).

\section{HASIL DAN PEMBAHASAN Karakterisasi Kitosan}

Gambar 1 menunjukkan hasil karakterisasi kitosan menggunakan metode FTIR. Spektra FTIR menunjukkan bahwa pola serapan yang muncul pada kitosan cangkang kepiting pada panjang gelombang $3572,58 \mathrm{~cm}^{-1}$ menunjukkan vibrasi $\mathrm{OH}$. Puncak serapan lainnya terjadi pada panjang gelombang2850,46 $\mathrm{cm}^{-1}$ menunjukkan vibrasi ulur dari gugus $\mathrm{C}-\mathrm{H}$ metilen (Puspawati dan Simpen, 2010). Pada bilangan gelombang 1559,83 cm-1598,51 cm terdeteksi puncak yang menunjukkan bending vibration gugus $-\mathrm{NH}_{2}$. Bending vibration pada C-H muncul pada rentang 1410,37 cm $\mathrm{cm}^{-1}-1429,91 \mathrm{~cm}^{-1}$ (Irawan et al., 2018). Pada panjang gelombang $878,19 \mathrm{~cm}^{-1}$ terdeteksi puncak yang menunjukkan vibrasi dari gugus kibasan $-\mathrm{NH}_{2}$ (Puspawati dan Simpen, 2010).

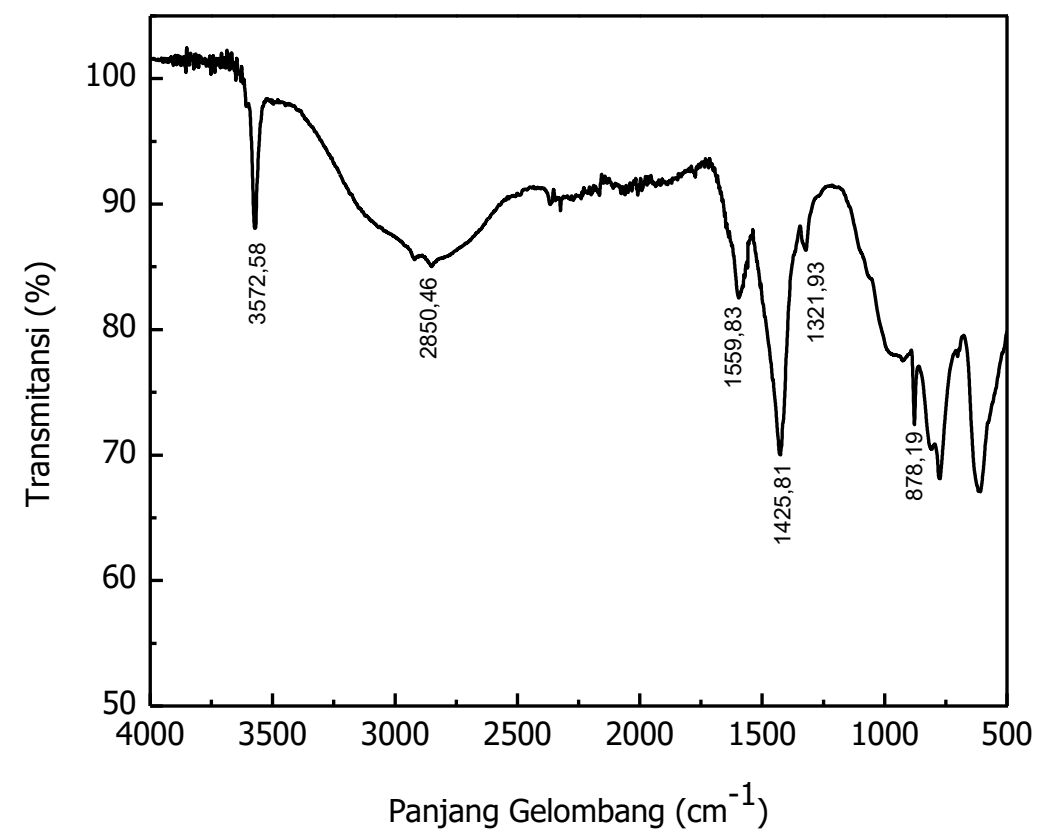

Gambar 1. Spektra FTIR Kitosan Cangkang Kepiting 
Hasil analisis mutu kitosan disajikan pada Tabel. 1. Berdasarkan hasil analisis tersebut menunjukkan bahwa kadar lemak belum memenuhi standar mutu sedangkan kadar air, abu, protein, dan derajat deasitilasi kitosan telah memenuhi standar mutu. Nilai kadar air pada penelitian ini yaitu sebesar $6,35 \%$. Besarnya nilai tersebut dipengaruhi oleh proses dan lama pengeringan, jumlah kitosan yang dikeringkan, luas permukaan tempat kitosan dan kondisi penyimpanan kitosan.Jumlah mineral yang terkandung dalam kitosan dapat dilihat dari kadar abunya (Aisyah dkk., 2017). Tahap demineralisasi pada penelitian ini mampu menghasilkan kitosan dengan kadar abu 2,54\%. Nilai kadar abu ini telah memenuhi standar mutu dimana nilainya maksimal $5 \%$.Kadar protein pada penelitian ini yaitu sebesar $1,73 \%$. Nilainya telah memenuhi standar mutu yaitu sebesar $\leq 5 \%$. Derajat deastilasi menunjukkan persentase penghilangan gugus asetil yang diganti dengan amina. Hasil analisis menunjukkan bahwa derajat deasilasi yang dihasilkan sudah memenuhi standar mutu kitosan.

Tabel 1. Hasil Analisis Mutu Kitosan cangkang Kepiting

\begin{tabular}{lcc}
\hline Parameter & Hasil analisis (\%) & Standart mutu (\%) \\
\hline Kadar air & 6,35 & Maks. 12* \\
Kadar abu & 2,54 & Maks. 5* \\
Kadar protein & 1,73 & $5 *$ \\
Derajat Deasetilasi & 76,10 & $>60^{* *}$ \\
\hline Keterangan: *Aisyah et al., (2017); **Dompeipen et al., (2016)
\end{tabular}

\section{Koagulasi Ferri Klorida}

Hasil pengujian karakteristik $\mathrm{BOD}_{5}, \mathrm{COD}$, MBAS limbah laundry sebelum ditambahkan koagulan disajikan pada Tabel 2. Hasil pengujian parameter tersebut selanjutnya dibandingkan Baku Mutu Air Limbah bagi Usaha dan/atau Kegiatan Laundrydalam Pergub Jatim No 72 Tahun 2013 untuk parameter $\mathrm{BOD}_{5}, \mathrm{COD}$, MBAS.Berdasarkan hasil uji menunjukkan bahwa parameter $\mathrm{BOD}_{5}$ dan $\mathrm{COD}$ tidak memenuhi standar baku mutu sedangkan parameter MBAS telah memenuhi baku mutu.

Tabel 2. Hasil Analisis Karakteristik Limbah Laundry

\begin{tabular}{lccc}
\hline Parameter & Satuan & Hasil analisis & Standart Baku Mutu \\
\hline COD & $\mathrm{mg} / \mathrm{L}$ & 662,25 & 250 \\
$\mathrm{BOD}_{5}$ & $\mathrm{mg} / \mathrm{L}$ & 263,88 & 100 \\
MBAS & $\mathrm{mg} / \mathrm{L}$ & 8,52 & 10 \\
$\mathrm{pH}$ & - & 7,5 & $6-9$ \\
\hline
\end{tabular}

Efisiensi penyisihan dari masing-masing koagulan terhadap parameter pencemar perlu dihitung untuk mengetahui keberhasilan proses pengolahan limbah laundry menggunakan

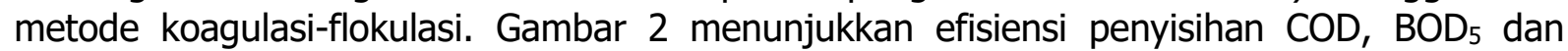
surfaktan anionik (MBAS) menggunakan ferri klorida. Hasil penelitian menunjukkan bahwa bahwa peningkatan dosis ferri klorida dari 100 sampai dengan $200 \mathrm{mg} / \mathrm{L}$ menyebabkan peningkatan efisiensi penyisihan $\mathrm{COD}, \mathrm{BOD}_{5}$ dan surfaktan anionik (MBAS). Efisiensi penyisihan maksimal $\mathrm{COD}, \mathrm{BOD}_{5}$ dan surfaktan anionik diperoleh pada dosis ferri kloridasebesar $250 \mathrm{mg} / \mathrm{L}$ dengan nilai masing-masing sebesar 79,93\%, 64,17\%, dan 64,24\%. Penambahan ferri klorida ke dalam air limbah menghasilkan ferri hidroksida sehingga dapat memfasilitasi pengendapan koloid dan meningkatkan laju sedimentasi senyawa organik yang terkandung di dalam air limbah (Abu Bakar dan Halim, 2013). Larasati et al. (2017) dalam penelitian yang serupa menggunakan senyawa ferri klorida sebagai koagulan dalam 
pengolahan limbah laundry yang menunjukkan bahwa peningkatan dosis koagulan ferri klorida dari $500-1500 \mathrm{mg} / \mathrm{L}$ menyebabkan peningkatan efisiensi penyisihan COD. Efisiensi penyisihan COD limbah laundry maksimum terjadi pada konsentrasi $1500 \mathrm{mg} / \mathrm{L}$ dengan nilai sebesar 73,79\%. Aboulhassan et al. (2006) melaporkan bahwa penggunaan $\mathrm{FeCl}_{3}$ cukup efektif menyisihkan parameter COD dan surfaktan dari air limbah mikroelektronik dengan efisiensi penyisihan masing-masing sebesar 99\% dan 88\%. Aygun dan Yilmaz (2010) melaporkan bahwa penggunaan senyawa ferri klorida dengan dosis $1,5 \mathrm{~g} / \mathrm{L}$ dan $\mathrm{pH} 11$ pada limbah residu pencucian deterjen menghasilkan efisiensi penyisihan COD optimum yaitu sebesar $57 \%$. Hasil penelitian menunjukkan bahwa penggunaan senyawa ferri klorida cukup efektif menyisihkan parameter COD di dalam limbah laundry.

Proses mekanisme koagulasi-flokulasi menggunakan ferri klorida di dalam air limbah diawali dengan pelarutan hidrolisis yang menghasilkan ion $\mathrm{Fe}^{3+}$ dan $\mathrm{Cl}^{-}$. Ion Fe selanjutnya bereaksi dengan komponen alkalinitas di dalam air limbah menghasilkan sedimen $\mathrm{Fe}(\mathrm{OH})_{3}$ dengan persamaan reaksi (2) berikut (Mustafa dan Peter, 2016):

$$
2 \mathrm{FeCl}_{3}+3 \mathrm{Ca}\left(\mathrm{HCO}_{3}\right)_{2} \rightarrow 2 \mathrm{Fe}(\mathrm{OH})_{3}+3 \mathrm{CaCl}_{2}+6 \mathrm{O}_{2}
$$

Muatan spesies hasil hidrolisis tergantung pada kondisi PH larutan. Spesies hidrolisis bermuatan positif pada $\mathrm{pH}$ rendah $(<6)$ dan bermuatan negatif pada $\mathrm{pH}$ tinggi.Peningkatan dosis ferri klorida mengarah pada konsumsi alkanitas yang tinggi sehingga menyebabkan penurunan $\mathrm{pH}$ larutan. Spesies hidrolisis tersebut dapat teradsorpsi pada permukaan partikel koloid dan mendestabilkan partikel koloid. Pada proses destabilisasi terjadi proses netralisasi muatan koloid sehingga terbentuk endapan yang dapat menyapu partikel koloid yang menyebabkan penurunan parameter $\mathrm{BOD}_{5}, \mathrm{COD}$, dan MBAS (Aygun dan Yilmaz, 2010).

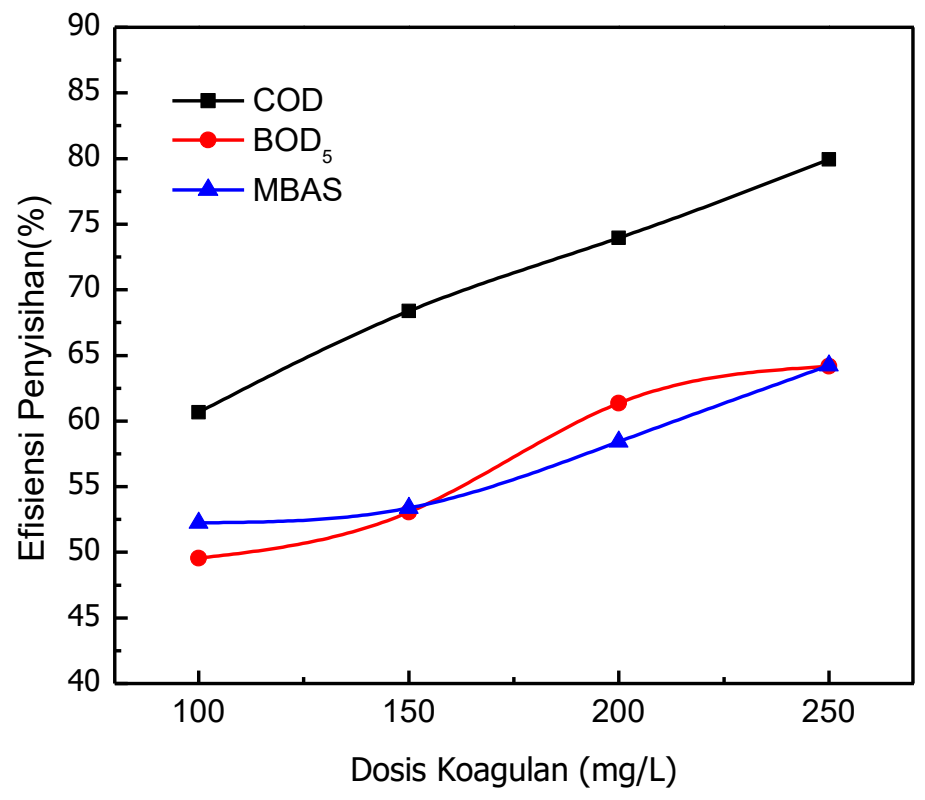

Gambar 2. Efisiensi Penyisihan Dengan Koagulan Ferri Klorida

\section{Koagulasi Kitosan}

Gambar 3 menunjukkan kinerja koagulan kitosan dalam proses pengolahan limbah laundry. Hasil penelitian menunjukkan bahwa penigkatan dosis koagulan kitosan dari $100 \mathrm{mg} / \mathrm{L}$ sampai $200 \mathrm{mg} / \mathrm{L}$ menyebabkan peningkatan efisiensi penyisihan $\mathrm{COD}, \mathrm{BOD}_{5}$, dan MBAS yang terkandung di dalam air limbah. Dosis optimum koagulan terjadi pada $200 \mathrm{mg} / \mathrm{L}$ kitosan dengan efisiensi penyisihan $\mathrm{COD}, \mathrm{BOD}_{5}$, dan MBAS masing-masing sebesar $63,94 \%, 56,43 \%$, 
dan 76,98\%. Kondisi efisiensi penyisihan parameter air limbah tersebut disebabkan peningkatan densitas muatan akibat peningkatan dosis kitosan pada dosis $200 \mathrm{mg} / \mathrm{L}$ dimungkinkantingkat adsorpsi mencapai maksimum untuk destabilisasi partikel. Namun pada dosis kitosan $250 \mathrm{mg} / \mathrm{L}$ terjadi penurunan efisiensi penyisihan parameter limbah. Penurunan tersebut disebabkan adsorpsi polimer kitosan yang berlebih pada permukaan partikel menghasilkan restabilisasi partikel sehingga menyebabkan gaya tolak elektrostatik antar koloid. Dosis kitosan yang tinggi memungkinkan pembalikan muatan sehingga menyebabkan stabilisasi partikel (Devi et al., 2012).

Hasil penelitian penggunaan kitosan sebagai koagulan limbah laundry pada dosis 200 $\mathrm{mg} / \mathrm{L}$ menghasilkan efisiensi penyisihan MBAS lebih tinggi dibandingkan dengan penyisihan COD dan BOD $_{5}$.Efisiensi penyisihan MBAS pada dosis kitosan dan ferri klorida $200 \mathrm{mg} / \mathrm{L}$ masing-masing sebesar $76,98 \%$ dan $64,24 \%$. Kitosan memiliki keunggulan dalam menyisihkan parameter MBAS lebih baik dibandingkan dengan ferri klorida pada dosis $200 \mathrm{mg} / \mathrm{L}$. Hal tersebut disebabkan pada proses koagulasi polimer kitosan membawa muatan positif di sepanjang rantai molekulnya yang efektif berperan sebagai koagulan pada koloid yang bermuatan negatif (surfaktan anionik) membentuk kompleks agregat surfaktan-polimer yang mampu mengendap. Penambahan koagulan yang bermuatan positif dapat mengurangi gaya tolakmenolak antar partikel koloid serta memungkinkan penggabungan partikel koloid membentuk inti partikel yang lebih besar sehingga lebih mudah untuk diendapkan (Chopra dan Ruhi, 2016).

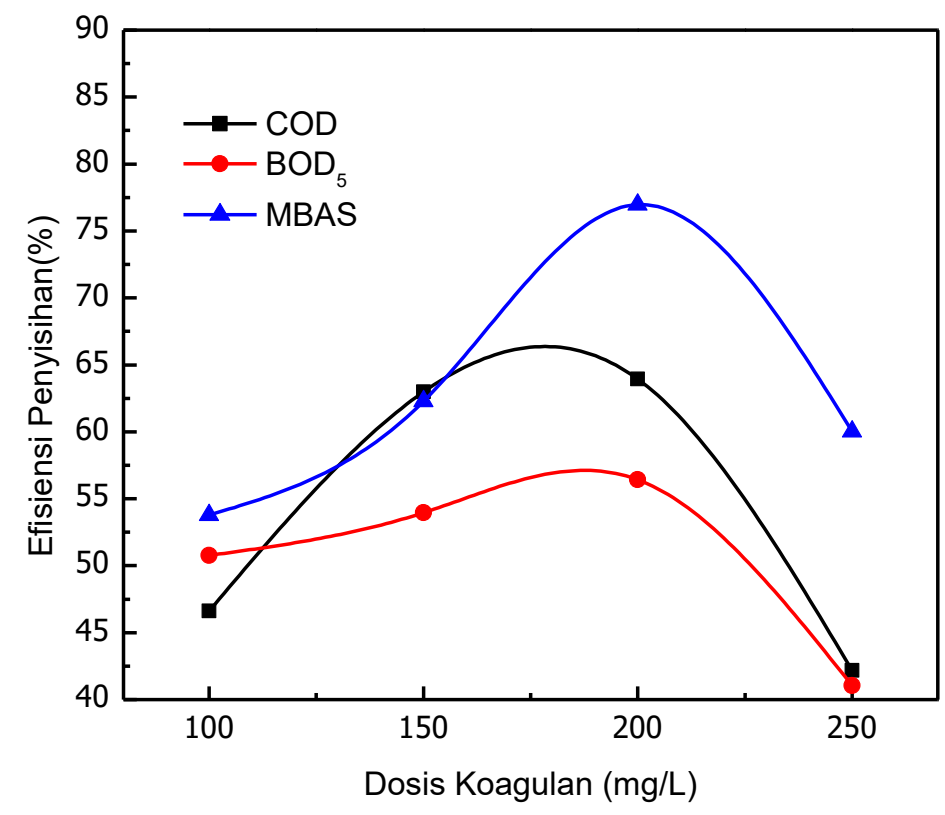

Gambar 3. Efisiensi Penyisihan Dengan Koagulan Kitosan

\section{Koagulasi Kombinasi Ferri Klorida dan Kitosan}

Hasil analisis proses pengolahan limbah laundry dengan koagulasi menggunakan koagulan ferri klorida $100 \mathrm{mg} / \mathrm{L}$ memiliki efisiensi penyisihan terendah dibandingkan dengan penggunaanferri klorida pada dosis 150, 200, dan 250mg/L. Pada dosis $100 \mathrm{mg} / \mathrm{L}$ ferri klorida menghasilkan efiensi penyisihanCOD, $\mathrm{BOD}_{5}$ dan MBASmasing-masing sebesar $60,67 \%$, 49,54\%, dan 52,26\%. Rendahnya efisiensi penyisihan pada dosis $100 \mathrm{ppm}$ dapat dioptimalkan dengan kombinasi menggunakan koagulan kitosan pada dosis yang lebih rendah yaitu 20,40, 60 , dan $80 \mathrm{mg} / \mathrm{L}$. Koagulan kitosan dalam proses ini yaitu berperan sebagai koagulan pembantu. 


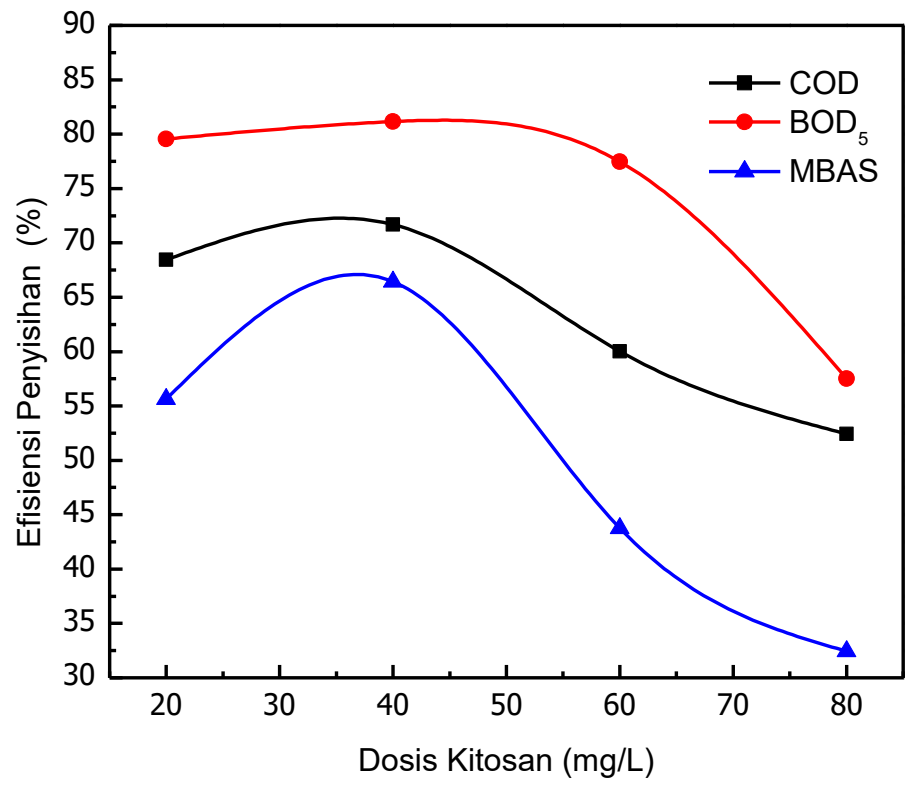

Gambar 4. Efisiensi Penyisihan kombinasi Kitosan dan 100 mg/L Ferri Klorida

Gambar 4 menunjukkan bahwa efiensi penyisihan parameter $\mathrm{COD}, \mathrm{BOD}_{5}$ dan $\mathrm{MBAS}$ mengalami peningkatan seiring dengan peningkatan dosis koagulan kitosan mulai $20 \mathrm{mg} / \mathrm{L}$ sampai dengan $40 \mathrm{mg} / \mathrm{L}$. Efisiensi penyisihan mencapai nilai maksimal pada dosis kombinasi $40 \mathrm{mg} / \mathrm{L}$ kitosan dan $100 \mathrm{mg} / \mathrm{L}$ ferriklorida. Besarnya efisiensi penyisihan $\mathrm{COD}, \mathrm{BOD}_{5}$ dan $\mathrm{MBAS}$ masing-masing sebesar $71,67 \%, 81,14 \%$, dan 66,24\%. Namun, pada dosis koagulan kitosan 60 ppm dan 80 ppm terjadi penurunan efisiensi penyisihan $\mathrm{COD}_{1} \mathrm{BOD}_{5}$ dan MBAS. Hal tersebut menunjukkan bahwapeningkatandosis koagulan kitosan lebih tinggi dari $40 \mathrm{mg} / \mathrm{L}$ menyebabkan restabilisasi koloid sehingga menyebabkan penurunan efisiensi penyisihan $\mathrm{COD}, \mathrm{BOD}_{5}$ dan $\mathrm{MBAS}$.

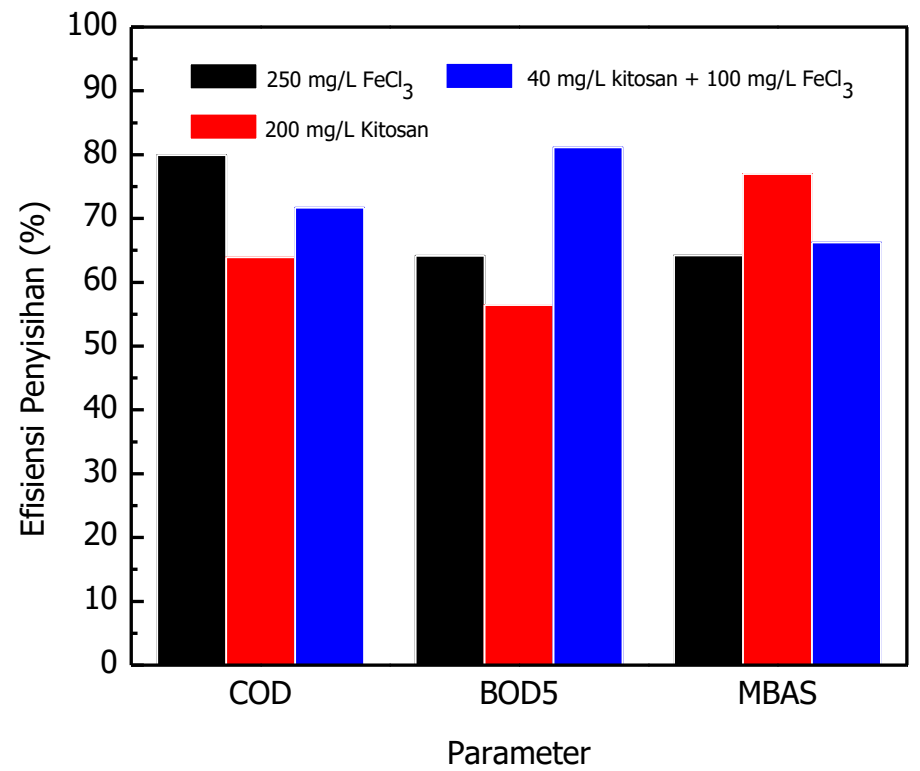

Gambar 5. Perbandingan Efisiensi Penyisihan Koagulan Pada Kondisi Optimum

Gambar 5 menunjukkan bahwa kombinasi kitosan-ferri klorida pada dosis optimum kitosan sebesar $40 \mathrm{mg} / \mathrm{L}$ memiliki efisiensi penyisihan $\mathrm{BOD}_{5}$ dan $\mathrm{MBAS}$ yang relatif lebih tinggi dibandingkan dengan penggunaan $250 \mathrm{mg} / \mathrm{L}$ ferri klorida. Besarnya kenaikan efisiensi 
penyisihan $\mathrm{BOD}_{5}$ dan MBAS tersebut masing-masing sebesar $16,97 \%$ dan $2 \%$. Penambahan kitosan dengan dosis $40 \mathrm{mg} / \mathrm{L}$ bersama dengan $100 \mathrm{mg} / \mathrm{L}$ ferri klorida menunjukkan hasil yang cukup efektif dalam menyisihkan $\mathrm{COD}, \mathrm{BOD}_{5}$, serta MBAS (surfaktan anionik) di dalam limbah laundry. Proses koagulasi kombinasi ferri klorida dan kitosan terjadi melalui mekanisme sebagai berikut yaitu interaksi elektrostatik atau netralisasi muatan (muatan positif dari ion $\mathrm{Fe}^{3+}$ dan ion positif hasil protonasi gugus amina kitosan), pembentukan ikatan hidrogen antara gugus hidroksil kitosan dengan komponen organik di dalam air limbah, serta pembentukan jembatan polimer yang dapat teradsorpsi pada partikel koloid sehingga membentuk flok yang lebih besar ( $\mathrm{Ng}$ et al., 2013). Hal tersebut yang menyebabkan kombinasi ferri klorida dan kitosan pada dosis yang rendah cukup efektif dalam menyisihkan komponen organik $\mathrm{BOD}_{5}$, COD, maupun MBAS yang terlarut di air limbah. Berdasarkan data Gambar 5 menunjukkan bahwa penggunaan koagulan yang menghasilkan parameter $\mathrm{BOD}_{5}, \mathrm{COD}$, maupun MBAS sesuai dengan baku mutu yaitu koagulan tunggal $250 \mathrm{mg} / \mathrm{L}$ ferri klorida dan kombinasi $40 \mathrm{mg} / \mathrm{L}$ kitosan $+100 \mathrm{mg} / \mathrm{L}$ ferri klorida. Hal ini menunjukkan bahwa penggunaan kombinasi koagulan kitosan pada dosis yang rendah dapat meningkatkan efektifitas penyisihan komponen organik serta mengurangi penggunaan ferri klorida pada proses koagulasi-flokulasi

\section{KESIMPULAN}

Limbah cangkang kepiting dapat dimanfaatkan menghasilkan koagulan kitosan dalam proses pengolahan limbah laundry. Deasetilasi kitin cangkang kepiting pada suhu $125^{\circ} \mathrm{C}$ menggunakan $\mathrm{NaOH} 60 \%$ selama 6 jam menghasilkan karakteristik kitosan dengan derajat deasetilasi sebesar $76,1 \%$. Hasil pengujian kitosan sebagai koagulan tunggal melalui jar test menunjukkan bahwa peningkatan dosis kitosan dari $100 \mathrm{mg} / \mathrm{L}$ sampai dengan $200 \mathrm{mg} / \mathrm{L}$ menyebabkan peningkatan efisiensi penyisihan $\mathrm{BOD}_{5}, \mathrm{COD}$, dan MBAS pada limbah laundry. Pada konsentrasi $200 \mathrm{mg} / \mathrm{L}$ kitosan diperoleh efisiensi penyisihan maksimal pada $\mathrm{COD}_{1} \mathrm{BOD}_{5}$, dan MBAS masing-masing sebesar 63,94\%, 56,43\%, dan 76,98\%. Penggunaan $250 \mathrm{mg} / \mathrm{L}$ koagulan tunggal ferri klorida menghasilkan efisiensi penyisihan maksimal $\mathrm{COD}, \mathrm{BOD}_{5}$, dan MBAS dengan nilai masing-masing sebesar 79,93\%, 64,17\%, dan 64,24\%. Kombinasi koagulan $40 \mathrm{mg} / \mathrm{L}$ kitosan bersama dengan $100 \mathrm{mg} / \mathrm{L}$ ferri klorida dapat menghasilkan efisiensi penyisihan $\mathrm{COD}, \mathrm{BOD}_{5}$, dan MBAS sebesar 71,67\%, 81,14\%, dan 66,24\%. Hal tersebut menunjukkan bahwa penambahan koagulan kitosan dapat memperbaiki kinerja pada koagulasi limbah laundry menggunakan ferri klorida. Hasil penelitian menunjukkan bahwa pada dosis optimum penggunaan $40 \mathrm{mg} / \mathrm{L}$ kitosan dengan ferri klorida $100 \mathrm{mg} / \mathrm{L}$ dapat mengurangi penggunaan ferri klorida sebesar $84 \%$.

\section{DAFTAR PUSTAKA}

Aboulhassan, M. A., Souabi, S., Yaacoubi, A., dan Baudu, M. 2006. Removal of surfactant from Industrial Wastewaters By Coagulation Flocculation Process. International Journal of Environmental Science and Technology 3(4): 327-332.

Abu Bakar, A.F., and Halim, A.A. 2013. Treatment of Automotive Wastewater by CoagulationFlocculation Using Poly-Aluminum Chloride (PAC), Ferric Chloride $\left(\mathrm{FeCl}_{3}\right)$ and Aluminum Sulfate (Alum). AIP Conference Proceedings 1571(1): 524-529.

Adesoye, A.M., Olayinka, K., Olukomaiya, O.O., dan Iwuchukwu, P.O. 2014. The Removal of Phosphates from Laundry Wastewater Using Alum and Ferrous Sulphate as Coagulants. International Journal of Innovation and Scientific Research 8(2): 256-260.

Aisyah, S., Agustina, Adawyah, R., dan Candra. 2017. Daya Hambat Kitosan dari Cangkang Limbah Budidaya Kepiting "Soka " terhadap Empat Isolat Bakteri Pembentuk Histamin Pada Ikan Tongkol (Euthynnus affinis). Seminar Nasional Lahan Basah ULM: 266-272 
Al-Manhel, A.J., Al-Hilphy, A.R.S., dan Niamah, A.K. 2018. Extraction of Chitosan, Characterisation and Its Use for Water Purification. Journal of the Saudi Society of Agricultural Sciences 17: 186-190.

Analysis of the Association of Official Analytical and Chemists (AOAC). 1999. Official Methods of Analysis of the Association of Official Analytical Chemists $16^{\text {th }}$ ed. AOAC International. USA, Rockville.

Aygun, A., dan Yilmaz, T. 2010. Improvement of Coagulation-Flocculation Process for Treatment of Detergent Wastewaters Using Coagulant Aids. International Journal of Chemical and Environmental Engineering 1(2): 97-101.

BSN(Badan Standardisasi Nasional). 2009. Standard Nasional Indonesia, SNI 6989.2-2009. Cara Uji COD Dengan Refluks Tertutup Secara Spektrofotometri.Jakarta, Indonesia: BSN.

BSN(Badan Standardisasi Nasional). 2009. Standard Nasional Indonesia, SNI 6989.72-2009. Cara Uji Kebutuhan Oksigen Biokimia (BOD). Jakarta, Indonesia: BSN.

BSN(Badan Standardisasi Nasional). 2005. Standard Nasional Indonesia, SNI 06-6989.512005. Cara Uji Kadar Surfaktan Anionik Dengan Spektrofotometer. Jakarta, Indonesia: BSN.

Bergamasco, R., Konradt-Moraes, L.C., Vieira, M.F., Fagundes-Klen, M.R., dan Vieira, A.M.S. 2011. Performance of a Coagulation-Ultrafiltration Hybrid Process for Water Supply Treatment. Chemical Engineering Journal 166: 483-489.

Braga, J.K. dan Varesche, M.B. 2014. Commercial Laundry Water Characterization. American Journal of Analytical Chemistry 5(1): 8-16.

Chopra, H., dan Ruhi, G. 2016. Eco Friendly Chitosan: An Efficient Material for Water Purification. The Pharma Innovation Jurnal 5(1): 92-95.

Daud, Z., Nasir, N., and Awang, H. 2013. Treatment of Biodiesel Wastewater by Coagulation and Flocculation Using PAC. Aust. J. Basic \& Appl. Sci. 2013(7): 258-262.

Devi, M.G., Al-Hashmi, Z.S.S., dan Sekhar, G.C. 2012. Treatment of Vegetable Oil Mill Effluent Using Crab Shell Chitosan as Adsorbent. International Journal of Environmental Science and Technology 9(4): 713-718.

Dompeipen, E.J., Kaimudin, M., dan Dewa, R. P. 2016. Isolasi Kitin dan Kitosan dari Limbah Kulit Udang. Jurnal Majalah BIAM 12(1): 32-39.

Ge, J., Qu, J., Lei, P., dan Liu, H. 2004. New Bipolar Electrocoagulation-Electroflotation Process for the Treatment of Laundry Wastewater. Separation and Purification Technology 36(1): 33-39.

Hongxia, M.A. dan Yaocang, L.I. 2012. The Preparation and Application of Chitosan Compound Flocculant. Meteorol. Environ. Res. 478: 22-24.

Irawan, C., Nata, I. F., Putra, M. D., Marisa, R., Asnia, M., dan Arifin, Y. F. 2018. Biopolimer Kitosan dari Sisik Ikan Sebagai Koagulant Alami untuk Pengolahan Air Tanah Terkontaminasi Besi. Jurnal Rekayasa Kimia Dan Lingkungan13(2): 93-99.

Janpoor, F., Torabian, A., dan Khatibikamal, V. 2011. Treatment of Laundry Waste-Water by Electrocoagulation. Journal of Chemical Technology and Biotechnology 86(8): 11131120.

Larasati, A., Darundiati, Y. H., dan Dangiran, H. L. 2017. Efektivitas Ferri Klorida $\left(\mathrm{FeCl}_{3}\right)$ dalam Menurunkan Kadar Chemical Oxygen Demand (COD) pada Limbah Cair Laundry. Jurnal Kesehatan Masyarakat5(5): 479-491.

Mashitah, S., Daud, S., dan Asmura, J. 2017. Penyisihan Kadar Fosfat pada Limbah Cair Laundry Menggunakan Biokoagulan Cangkang Kepiting (Brachyura). Jurnal Online Mahasiswa Fakultas Teknik Universitas Riau 4(2): 1-6.

Middleton, F.M. 1997. Advanced Water Treatment Technology in Water Reuse,Water Renovation and Reuse. New York. Academic press, 3-10. 
Mohadi, R., Kurniawan, C., Yuliasari, N., dan Hidayati, N. 2014. Karakterisasi Kitosan dari Cangkang Rajungan dan Tulang Cumi dengan Spektrofotometer FT-IR Serta Penentuan DerajatDeasetilasi Dengan Metode Baseline. Seminar Nasional FMIPA UNSRI. 2 Oktober: $1-10$.

Muthuraman, G., dan Sasikala, S. 2014. Removal of Turbidity from Drinking Water Using Natural Coagulants. Journal of Industrial and Engineering Chemistry 20(4): 1727-1731.

Nascimento, C.O.C., Veit, M.T., Palacio, S.M., Gonçalves, G.C., dan Fagundes-Klen, M.R. 2019. Combined Application of Coagulation/Flocculation/Sedimentation and Membrane Separation for the Treatment of Laundry Wastewater. International Journal of Chemical Engineering 2019: 1-13.

Ng, M., Liu, S., Chow, C.W.K., Drikas, M., Amal, R., dan Lim, M. 2013.Understanding Effects of Water Characteristics on Natural Organic Matter Treatability by PACl and a Novel PAClChitosan Coagulants. Journal of Hazardous Materials 263(2013): 718-725.

Puspawati, N. M., dan Simpen, I. N. 2010. Optimasi Deasetilasi Khitin dari Kulit Udang dan Cangkang Kepiting Limbah Restoran Seafood Menjadi Khitosan Melalui Variasi Konsentrasi $\mathrm{NaOH}$. Jurnal KimiaA(1): 79-90.

Putri, D.A.C., Joko, T., dan Yunita, N. A. 2015. Kemampuan Koagulan Kitosan dengan Variasi Dosis dalam Menurunkan Kandungan COD dan Kekeruhan pada Limbah Cair Laundry (Studi pada Rahma Laundry, Kecamatan Tembalang, Kota Semarang ). Jurnal Kesehatan Masyarakat, 3(3): 711-722.

Renaut, F., Sancey, B., Badot, P.M., dan Crini, G. 2009. Chitosan for Coagulation/Flocculation Processes-An Eco-friendly Approach. European Polymer Journal 45(5): 1332-1348.

Sahu, O.P. dan Chaudhari, P.K. 2013. Review on Chemical treatment of Industrial Waste Water.Journal of Applied Sciences and Environmental Management 17(2): 241-257.

Silva, T. L., Ronix, A., O., Pezoti , O., Souza, L.S., Leandro, P.K.T., Bedin, K.C., Beltrame, K.K., Cazetta, A.L., dan Almeida, V.C. 2016. Mesoporous Activated Carbon from Industrial Laundry Sewage Sludge: Adsorption Studies of Reactive Dye Remazol Brilliant Blue R. Chemical Engineering Journal 303: 467-476.

Terechova, E.L., Zhang, G., Chen, J., Sosnina, N.A., dan Yang, F. 2014. Combined Chemical Coagulation-Flocculation/Ultraviolet Photolysis Treatment for Anionic Surfactants in Laundry Wastewater. Journal of Environmental Chemical Engineering 2(4): 2111-2119.

Zemmouri, H., Drouiche, M., Sayeh, A., Lounici, H., dan Mameri, N. 2013. Chitosan Application For Treatment of Beni- Amrane's Water Dam. Energy Procedia 36(2013): 558-564.

Zheng, W., Migui, Z., Lei, H., Qiao, X., Zizeng, L., dan Lei, C. 2017. Research on PAC-CTS Composite Flocculant for The Decolorization of Reactive Blue 19. Ind. Water Treatment 9: 21-25. 